International Journal of Research in Engineering and Innovation
(IJREI)
jJ 1 ISSN (Online): 2456-6934

\title{
New methods to enhance the mechanical characteristics of welded joints of dissimilar Al-alloys by friction stir welding
}

\author{
Husain Mehdi, R.S Mishra
}

Department of Mechanical Engineering, Delhi Technological University Delhi, India

\begin{abstract}
The friction stir welding is a newer technique used for refining and homogenizing the grain structure of metal sheet. Friction stir processing is a great potential in the field of super plasticity and metal matrix composites. Many investigators observed that the FSW greatly enhances mechanical properties of welded joints of $\mathrm{Al}$ alloys. It is a solid-state welding technique which is specially designed rotating cylindrical tool that comprises of a probe and shoulder. The probe of the tool is inserted into the sheet material while rotating and the shoulder moves over the surface of the sheet, and then traverses in the desired direction. The contact between the rotating probe and the sheet material generate heat due to friction which softens the material and the mechanical stirring caused by the probe, the material within the processed zone undergoes intense plastic deformation yielding a dynamically-recrystallized fine grain microstructure. In this paper, the FSP tool pin rotates on an already welded joint by TIG welding to improve the lower the welding load and weld quality by adjusting the processing parameters of friction stir processing of different aluminum alloy.
\end{abstract}

(C) 2020 ijrei.com. All rights reserved

Keywords: $T I G$ welding, Friction stir welding, aluminum alloys, rotational speed.

\section{Introduction}

The coarse grain structure, micro crack and porosity were found in fusion welding like tungsten inert gas welding obtained due to persisting thermal conditions. when the fusion zone start to solidify. The formation of these defects on the weld region will result in reduction of weld strength about to half the parent material. To avoid these defects friction stir welding was introduced in 1991. The friction stir welding destroyed the coarse grain dendritic structure and generate new fine grain structure. Because of change in grains refinement and microstructure significantly improved the hardness of the friction stir processing (FSP) weld over the base metal.

The tool rotational speed, traverse speed, and tilt angle were basic parameters during the FSW process that have a substantial influence on the temperature distribution of the workpiece [1-2], the mechanical and metallurgical characterization of the welded joint [3] and material flow behavior [4]. The progress in numerical temperature simulations of FSW has been achieved by researchers and numerical analysis has found widespread application [5]. A moving source with a thermal distribution simulation the heat generated by friction between the rotating tool and the work-piece was used in a heat transfer analysis [6]. In past studies, the heat flux was calculated based on the assumption that the sliding friction at the tool work-piece interface and the material flow was ignored [7-8].

Due to low heat generation in the friction stir welding, the residual stresses were also low in the weldment. The transverse force of friction stir welding tools plays an important role in stress measurement. The residual stresses in the weldment have a big impact on the performance of the welded structure. So far, information on the residual stress distribution of FSW has been limited. The effects of tool feed rate on residual stresses of FSW of Al-alloy joints were studied with synchrotron X-ray measurement and analyze the residual stresses in longitudinal and transverse directions [9].

The literature consists of the work conducted on various aluminum alloys by friction stir welding/processing. The study consist of various parameters, tool materials, tool dimensions, response parameters and results obtained by various researchers on magnesium alloys by friction stir processing. The literature in the tabular form is given below. 


\begin{tabular}{|c|c|c|c|c|}
\hline Ref No & Author \& year & Material Used & Processing Parameter & Conclusions \\
\hline 10 & $\begin{array}{l}\text { J-Q-Su et al } \\
\text { [2002] }\end{array}$ & $\begin{array}{l}\text { Aluminum alloy } \\
7050-\mathrm{T} 65\end{array}$ & $\begin{array}{l}\text { The pin rotation speed was } \\
350 \mathrm{rpm} \text { and the pin travel } \\
\text { speed was } 15 \mathrm{~mm} / \mathrm{min}\end{array}$ & $\begin{array}{l}\text { Compared to parent material microstructure, the } \\
\text { strengthening precipitates have coarsened severely } \\
\text { and the precipitate free zone along the grain } \\
\text { boundaries has increased by factor of five during } \\
\text { friction stir welding, The original base metal grains } \\
\text { structure is completely eliminated and replaced by a } \\
\text { very fine equiaxed grain structure in the dynamic re- } \\
\text { crystallized zone (DXZ). }\end{array}$ \\
\hline 11 & $\begin{array}{l}\text { S.Jana, et al } \\
\text { [7] }\end{array}$ & $\begin{array}{l}\mathrm{Al}-7 \mathrm{Si}-0.6 \mathrm{Mg} \\
\text { alloy }\end{array}$ & $\begin{array}{l}\text { The FSP tool had a pin } \\
\text { height of } 1.9 \mathrm{~mm} \text {, a } \\
\text { diameter of } 4 \mathrm{~mm} \text { at mid- } \\
\text { pin height and a tool } \\
\text { shoulder diameter of } 12 \\
\text { mm. A process parameter } \\
\text { combination of } 2236 \mathrm{rpm} \\
\text { and } 2.33 \mathrm{~mm} / \mathrm{s} \\
\text { was used for the FSP runs }\end{array}$ & $\begin{array}{l}\text { FSP improved the fatigue life of a cast } \mathrm{Al}-7 \mathrm{Si}-0.6 \\
\mathrm{Mg} \text { alloy by a factor of } 15 \text { when specimens were } \\
\text { tested at the same stress level and at a stress ratio of } \\
\mathrm{R}=0 \text {. }\end{array}$ \\
\hline 12 & $\begin{array}{l}\text { Z.Y.Ma et al } \\
\text { [2002] }\end{array}$ & $\begin{array}{l}\text { 7075Aluminum } \\
\text { alloy }\end{array}$ & $\begin{array}{l}\text { Two different processing } \\
\text { parameters,i.e., } 4 \mathrm{ipm} / 400 \\
\text { rpm and } 6 \mathrm{ipm} / 350 \mathrm{rpm} \\
\text { were used to generate the } \\
\text { microstructures with } \\
\text { different grain sizes. }\end{array}$ & $\begin{array}{l}\text { Grain size will decrease in the temperature range of } \\
420-530 \text { and strain rate range of } 1 \times 10-3 \text { to } 10-1 \text {. For } \\
\text { the } 3.8 \mu \mathrm{m} 7075 \mathrm{Al} \text { alloy, super plastic elongation of } \\
1250 \% \text { were obtained at } 480 \text { in the strain rate range } \\
\text { of } 3 \times 10-3 \text { to } 3 \times 10-2 \mathrm{~s}-1 \text {, whereas the } 7.5 \mu \mathrm{m} 7075 \mathrm{Al} \\
\text { alloy exhibited a maximum ductility of } 1042 \% \text { at } \\
5000 \text { and } 3 \times 10-3 \mathrm{~s}-1\end{array}$ \\
\hline 13 & $\begin{array}{l}\text { R.S Mishra et } \\
\text { al [2003] }\end{array}$ & Al-SiC Composite & $\begin{array}{l}\text { Tool tranfer rate of } 25.4 \\
\mathrm{~mm} / \mathrm{min} \text { and } 101.6 \\
\mathrm{~mm} / \mathrm{min} \text { is used for } \\
\text { different target depth i.e. } \\
1.78 \mathrm{~mm}, 2.03 \mathrm{~mm}, 2.28 \mathrm{~mm}\end{array}$ & $\begin{array}{l}\text { When the target depth is too large }(2.28 \mathrm{~mm}) \text {, the } \\
\text { shoulder of tool pushed away all the preplaced } \mathrm{SiC} \\
\text { particles and basically no surface composite formed. } \\
\text { Too small target depth (1.78mm) was also } \\
\text { ineffective to mix Sic particles into Al-alloy. A } \\
\text { target depth of } 2.03 \mathrm{~mm} \text { resulted in incorporation of } \\
\text { SiC particles in Aluminum matrix. }\end{array}$ \\
\hline 14 & $\begin{array}{l}\text { S. Jana et al } \\
\text { [2007] }\end{array}$ & $\begin{array}{l}\text { Cast Al-Alloy of } \\
\text { F357 }\end{array}$ & $\begin{array}{l}\text { The tool rotation rate was } \\
2236 \mathrm{rpm} \text {, and tool traverse } \\
\text { speeds were } \\
0.42,0.98,2.33 \text { and } 3.67 \\
\mathrm{~mm} / \mathrm{s} \text {. }\end{array}$ & $\begin{array}{l}\text { The multiple pass does not resulted in Si particles } \\
\text { refined beyond a certain limit. The multi pass run of } \\
\text { second configuration indicate that the extent of AGG } \\
\text { can be reduced if the material is FSPed multiple } \\
\text { times }\end{array}$ \\
\hline 15 & $\begin{array}{l}\text { S. Jana et al } \\
\text { [2010] }\end{array}$ & $\begin{array}{l}\mathrm{Al}-7 \mathrm{Si}-0.6 \mathrm{Mg} \\
\text { alloy }\end{array}$ & $\begin{array}{l}\text { Tool rotation rate of } 2236 \\
\text { rpm and travel speed of } \\
2.33 \mathrm{~mm} / \mathrm{s}\end{array}$ & $\begin{array}{l}\text { FSP led to a five times improvement in fatigue life } \\
\text { for a hypoeutectic Al-Si-Mg cast alloy. The cast } \\
\text { fatigue specimen showed a life of } 45500 \text { cycles. As } \\
\text { expected crack were noted to have originated at } \\
\text { porosity when the test was stopped after the first } \\
5000 \text { cycles which implies a } 10 \% \text { or lower crack } \\
\text { initiation periods. }\end{array}$ \\
\hline 16 & $\begin{array}{l}\text { Z.Y.Ma et al } \\
\text { [2005] }\end{array}$ & $\mathrm{Al}-4 \mathrm{Mg}-1 \mathrm{Zr}$ & $\begin{array}{l}\text { The traverse speed of the } \\
\text { tool 4ipm and the rotation } \\
\text { rate of the tool } 350 \mathrm{rpm} \\
\text { was used }\end{array}$ & $\begin{array}{l}\text { A maximum super plastic ductility of } 1280 \text { pct was } \\
\text { observed at } 525 \mathrm{C} \text { and initial strain rate of } 1 \times 10-1 \mathrm{~s}- \\
1 \text {. The strain rate sensitivity of both as- extruded and } \\
\text { FSP Al- } 4 \mathrm{Mg}-1 \mathrm{Zr} \text { increased continuously with } \\
\text { increasing strain rate from } 1 \times 10-3 \mathrm{~s}-1 \text { to } 1 \mathrm{~s}-1 \text {. }\end{array}$ \\
\hline
\end{tabular}




\begin{tabular}{|c|c|c|c|c|}
\hline 17 & $\begin{array}{l}\text { S.R Sharma } \\
\text { [2004] }\end{array}$ & A356 Alloy & $\begin{array}{l}\text { One plate was processed } \\
\text { using a standard FSW pin } \\
\text { at } 900 \mathrm{rpm} \text { and a traverse } \\
\text { speed of } 203.2 \mathrm{~mm} \text { per } \\
\text { minute and the other plate } \\
\text { was processed using a } \\
\text { triflute pin at } 700 \mathrm{rpm} \text { and } \\
203.2 \mathrm{~mm} \text { per minute. }\end{array}$ & $\begin{array}{l}\text { Fatigue life improvement was attributed to } \\
\text { significant refinement, homogenization of the } \\
\text { microstructure and the elimination of porosity. FSP } \\
\text { resulted in a significant breakup and uniform } \\
\text { distribution of Si particles in the aluminum matrix as } \\
\text { well as elimination of porosity. }\end{array}$ \\
\hline 18 & $\begin{array}{l}\text { Z.Y.Ma et al } \\
\text { [2006] }\end{array}$ & Al-Si alloy A356 & $\begin{array}{l}\text { Five-pass FSP with a } \\
\text { toorotation rate of } 700 \mathrm{rpm} \\
\text { and a traverse speed of } 203 \\
\mathrm{~mm} / \mathrm{min} \text { was performed } \\
\text { using a tri-flute pin. }\end{array}$ & $\begin{array}{l}\text { Overlapping FSP did not affect the size, aspect ratio } \\
\text { and } \\
\text { distribution of the } \mathrm{Si} \text { particles. The } \mathrm{Si} \text { particles } \\
\text { broken by FSP were uniform distributed in the entire } \\
\text { processed zones created by multi pass FSP. }\end{array}$ \\
\hline 19 & $\begin{array}{l}\text { Z.Y.Ma et al } \\
\text { [2004] }\end{array}$ & Al-Si alloy A356 & $\begin{array}{l}\text { Single pass FSP with a tool } \\
\text { rotation rate of } 700 \mathrm{rpm} \\
\text { and transverse speed of } \\
203 \mathrm{~mm} / \mathrm{min} \text { was } \\
\text { performed on } 6.35 \mathrm{~mm}\end{array}$ & $\begin{array}{l}\text { The flow stress of FSP A356 was significantly lower } \\
\text { than } \\
\text { of cast A356 FSP. Maximum super plasticity of } \\
650 \% \text { was obtained at 530C and an initial strain rate } \\
\text { of } 1 \times 10-3 \text { s-1 in FSP A356. }\end{array}$ \\
\hline 20 & $\begin{array}{l}\text { Jianqing Su et } \\
\text { al [2013] }\end{array}$ & Ti-6Al-4V alloy & $\begin{array}{l}\text { Tool rotational speed } \\
(800-1000 \mathrm{rpm}) \text { and tool } \\
\text { traverse speed ( } 1- \\
4 \text { IPM) was used in this } \\
\text { work. }\end{array}$ & $\begin{array}{l}\text { The higher yield and ultimate tensile strength of } \\
1067 \text { MPa } \\
1156 \mathrm{MPa} \text { without any losses of ductility were } \\
\text { achieved in } 900 \mathrm{rpm} / 4 \mathrm{IPM} \text { sample having the } \\
\text { smallest prior } \beta \text { grains size of } \sim 12 \mu \mathrm{m}\end{array}$ \\
\hline 21 & $\begin{array}{l}\text { Omar.S.Salih } \\
\text { [2015] }\end{array}$ & $\begin{array}{l}\text { Aluminium matrix } \\
\text { composites } \\
\text { (AMCs) }\end{array}$ & $\begin{array}{l}\text { Tool rotaion speed was } \\
600,800 \text { and } 1000 \mathrm{rpm} \text { and } \\
\text { tool transverse speed was } \\
40,80 \mathrm{~mm} / \mathrm{min} \text { used }\end{array}$ & $\begin{array}{l}\text { Welding parameters such as tool rotation, speed, } \\
\text { transverse } \\
\text { speed and axial force have a significant effect on the } \\
\text { amount of heat generation and strength of FSW } \\
\text { joints. Microstructural evaluation showed the } \\
\text { formation of tunnel defect due to inappropriate flow } \\
\text { of plasticized metal }\end{array}$ \\
\hline 22 & $\begin{array}{l}\text { N.Kamp et al } \\
\text { [2006] }\end{array}$ & $\begin{array}{l}\text { AA7449 } \\
\text { aluminium alloy. }\end{array}$ & $\begin{array}{l}\text { The interfacial energy of } \\
\text { the different phases and the } \\
\text { diffusion rates was taken }\end{array}$ & $\begin{array}{l}\text { A numerical analytical model based on the } \\
\text { Kampmann and Wagner numerical (KWN) model } \\
\text { has been developed to predict the precipitate dis- } \\
\text { tribution evolution in } 7 \mathrm{xxx} \text { alloys during complex } \\
\text { processing. }\end{array}$ \\
\hline 23 & $\begin{array}{l}\text { M. Maalekian } \\
\text { et al [2008] }\end{array}$ & $\begin{array}{l}\text { Steel Bar having } \\
\text { Composition } \\
0.75 \mathrm{C}, 1.02 \mathrm{Mn} \\
0.28 \mathrm{Si}, 0.11 \mathrm{Cr} \\
0.05 \mathrm{Ni}, 0.015 \mathrm{~S} \\
0.009 \mathrm{P}, 0.08 \mathrm{Cu}\end{array}$ & $\begin{array}{l}\text { function of process } \\
\text { parameters } \\
\mathrm{q}=2 \pi \cdot \mathrm{n} . \mathrm{e} \cdot \mu . \mathrm{P} \\
\text { Where } \mathrm{q}=\text { heat flux, } \\
\mu=\text { Coulomb coefficient of } \\
\text { friction, } \mathrm{n}=\text { rotational } \\
\text { speed, } \mathrm{e}=\text { Amplitude, } \mathrm{P}= \\
\text { pressure }\end{array}$ & $\begin{array}{l}\text { The heat-generation rate in orbital friction welding } \\
\text { of steel bars is analyzed using four different } \\
\text { methods; constant Coulomb friction, sliding-sticking } \\
\text { friction, the experimentally measured power data } \\
\text { and an inverse heat conduction approach. }\end{array}$ \\
\hline 24 & $\begin{array}{l}\text { L. Fratini et al } \\
\text { [2010] }\end{array}$ & AA7075-T6 & $\begin{array}{l}\text { The tool rotation rate were } \\
715 \text { and } 1500 \mathrm{rpm} \text {, and tool } \\
\text { traverse speeds were } 105 \\
\text { and } 214 \mathrm{~mm} / \mathrm{min}\end{array}$ & $\begin{array}{l}\text { The effects of in process cooling on the material } \\
\text { characteristics } \\
\text { and joint performance have been presented on } \\
\text { AA7075-T6 }\end{array}$ \\
\hline 25 & $\begin{array}{l}\text { S. Mironov et } \\
\text { al [2011] }\end{array}$ & $\begin{array}{l}\text { S31254 } \\
\text { superaustenitic } \\
\text { stainless steel }\end{array}$ & $\begin{array}{l}\text { A tool rotational speed of } \\
400 \text { r.p.m. and a tool travel } \\
\text { speed of } 30 \mathrm{~mm} / \mathrm{min}\end{array}$ & $\begin{array}{l}\text { The structural response of a typical low stacking } \\
\text { fault energies (SFE) material S31254 to FSW has } \\
\text { been studied. Formation of the final stir zone (SZ) } \\
\text { microstructure was deduced to be primarily } \\
\text { governed by discontinuous recrystallization } \\
\text { occurring during the FSW cooling cycle. }\end{array}$ \\
\hline
\end{tabular}




\begin{tabular}{|c|c|c|c|c|}
\hline 26 & $\begin{array}{l}\text { Husain Mehdi } \\
\text { et al., [2020] }\end{array}$ & $\begin{array}{l}\text { AA6061 } \\
\text { AA7075 }\end{array}$ & $\begin{array}{l}\text { Tool rotational speed } \\
1000-1300 \mathrm{rpm} \text {, feed rate } \\
30-60 \mathrm{~mm} / \mathrm{min} \text {, } \\
\text { tilt angle } 0-2\end{array}$ & $\begin{array}{l}\text { The maximum tensile strength, percentage } \\
\text { elongation, micro-hardness at nugget zone are } 255 \\
\mathrm{MPa}, 29.2 \text { and } 105 \mathrm{HV} \text { at tool rotation } 1300 \mathrm{rpm} \text {, } \\
\text { traverse speed } 45 \mathrm{~mm} / \mathrm{min} \text { and tilt angle } 1^{0} \text {, whereas } \\
\text { maximum residual stress }(12.2 \mathrm{MPa}) \text { was found at } \\
\text { tool rotation } 1000 \mathrm{rpm} \text {, traverse speed } 60 \mathrm{~mm} / \mathrm{min} \\
\text { and tilt angle } 0^{0} \text {. The application of FSP on TIG } \\
\text { welded joint also improve the ductility of the welded } \\
\text { joints, TIG+FSP welded joints are more ductile than } \\
\text { the TIG welded joint due to fine grain structure. }\end{array}$ \\
\hline 27 & $\begin{array}{l}\text { Husain Mehdi } \\
\text { et al., [2020] }\end{array}$ & $\begin{array}{l}\text { AA6061 } \\
\text { AA7075 }\end{array}$ & $\begin{array}{l}\text { Tool rotational speed } 800- \\
1600 \mathrm{rpm} \text {, feed rate } 63 \\
\mathrm{~mm} / \mathrm{min}\end{array}$ & $\begin{array}{l}\text { The asymmetry of the temperature distribution } \\
\text { during TIG+FSP welding of AA7075 and AA6061 } \\
\text { determined by numerical simulation corresponded } \\
\text { with the experimental results. The peak temperatures } \\
\text { on AS were higher than the RS of } 20 \mathrm{~K} \text {. The heat } \\
\text { transfer is analyzed by the effect of different } \\
\text { processing parameters of FSP tool. The temperature } \\
\text { at advancing side is higher than the retreating side. } \\
\text { The predicted peak values of temperature at the weld } \\
\text { region was calculated by the ANSYS software and } \\
\text { found the maximum temperature about } 515^{\circ} \mathrm{C} \text { at tool } \\
\text { rotation of } 1600 \mathrm{rpm} \text {, whereas the maximum heat } \\
\text { flux rate about } 5.33 \times 10^{6} \text { was observed at } 1600 \mathrm{rpm}\end{array}$ \\
\hline 28 & $\begin{array}{l}\text { Y.S. Sato et al } \\
\text { [2004] }\end{array}$ & Al Alloy 1100 & $\begin{array}{l}\text { Rotation speed of the } \\
\text { welding tool was } 500 \mathrm{rpm} \text {, } \\
\text { and the traveling } \\
\text { speed was } 12 \mathrm{~mm} / \mathrm{sec}\end{array}$ & $\begin{array}{l}\text { Friction stir welding (FSW) was applied to an } \\
\text { accumulative roll-bonded (ARBed) Al alloy } 1100 . \\
\text { FSW resulted in reproduction of fine grains in the } \\
\text { stir zone and small growth of the ultrafine grains of } \\
\text { the ARBed material just outside the stir zone. }\end{array}$ \\
\hline 29 & $\begin{array}{l}\text { G. Buffa et al } \\
\text { [2011] }\end{array}$ & $\begin{array}{l}\text { A 3D FE model, } \\
\text { with general } \\
\text { validity for } \\
\text { different joint } \\
\text { configurations, was } \\
\text { used to simulate }\end{array}$ & $\begin{array}{l}\text { Tool rotating speed and tilt } \\
\text { angle were keptconstant } \\
\text { and equal to } 500 \mathrm{rpm} \text { and } \\
21 \text {, respectively. Three } \\
\text { levels of advancing } \\
\text { velocity, i.e. } 100,225 \text { and } \\
325 \mathrm{~mm} / \mathrm{min} \text { were selected. }\end{array}$ & $\begin{array}{l}\text { A new numerical procedure for the prediction of the } \\
\text { residual stress distributions in Friction Stir Welding } \\
\text { processes is Studied. }\end{array}$ \\
\hline 30 & $\begin{array}{l}\text { C. Hamilton et } \\
\text { al [2008] }\end{array}$ & $\begin{array}{l}\text { AA6061-T6 } \\
\text { Aluminum alloy }\end{array}$ & $\begin{array}{l}\text { Range of tool rotation rate } \\
50 \text { to } 550 \mathrm{rpm} \text { was used. }\end{array}$ & $\begin{array}{l}\text { A thermal model of friction stir welding was } \\
\text { developed that utilizes a new slip factor based on the } \\
\text { energy per unit length of weld. The thermal model } \\
\text { successfully predicts the maximum welding } \\
\text { temperature over a wide range of energy levels }\end{array}$ \\
\hline 31 & $\begin{array}{l}\text { Husain Mehdi } \\
\text { et al., [2020] }\end{array}$ & $\begin{array}{l}\text { AA6061 } \\
\text { AA7075 }\end{array}$ & $\begin{array}{l}\text { Tool rotational speed } \\
1000-1300 \mathrm{rpm} \text {, feed rate } \\
44 \mathrm{~mm} / \mathrm{min}\end{array}$ & $\begin{array}{l}\text { The maximum compressive residual stress } 64 \mathrm{MPa} \\
\text { were located at the fusion zone (FZ) of the TIG } \\
\text { weldment with filler ER } 4043 \text {, whereas minimum } \\
\text { compressive residual stress } 39 \text { MPa was obtained at } \\
\text { stir zone (SZ) of the TIG+FSP with filler } 5356 \text {. The } \\
\text { heat transfer is analyzed by the effect of different } \\
\text { processing parameters of FSP tool. The temperature } \\
\text { at advancing side is higher than the retreating side. } \\
\text { The predicted peak values of temperature at the weld } \\
\text { region was calculated by the ANSYS software and } \\
\text { found the maximum temperature about } 511^{\circ} \mathrm{C} \text { at tool } \\
\text { rotation of } 1300 \mathrm{rpm} \text {. }\end{array}$ \\
\hline
\end{tabular}




\begin{tabular}{|c|c|c|c|c|}
\hline 32 & $\begin{array}{l}\text { Husain Mehdi } \\
\text { et al., [2020] }\end{array}$ & $\begin{array}{l}\text { AA6061 and } \\
\text { AA7075 TIIM }\end{array}$ & $\begin{array}{l}\text { Tool rotational speed } \\
1000-1300 \mathrm{rpm} \text {, feed rate } \\
30-60 \mathrm{~mm} / \mathrm{min} \text {, } \\
\text { tilt angle } 0-2\end{array}$ & $\begin{array}{l}\text { The minimum compressive residual stress } 18 \mathrm{MPa} \text {, } \\
\text { maximum tensile strength ( } 281.1 \mathrm{MPa}) \text {, and } \\
\text { hardness }(107 \mathrm{HV}) \text { were located at the nugget zone } \\
\text { of the TIG+FSP weldment at tool rotation } 1300 \mathrm{rpm} \text {, } \\
\text { traverse speed } 30 \mathrm{~mm} / \mathrm{min} \text { with tilt angle } 2 \text {. The } \\
\text { large dimples and quasi cleavage with a sharp edge } \\
\text { and various depth were found on the fractured tensile } \\
\text { specimen surface of low tool rotational speed } \\
\text { whereas fine dimples were found at high tool } \\
\text { rotational speed. The average fine dimples }(4.3 \mu \mathrm{m}) \\
\text { were observed at high tool rotational speed. }\end{array}$ \\
\hline
\end{tabular}

\section{Conclusions}

The present investigation have been carried out to assess the influences of friction stir processing on TIG welded joints to observed the optimum combination of parameters to attain better mechanical and metallurgical properties of pulse TIG and TIG+FSP welded joints of dissimilar aluminum alloys AA6061 and AA7075. From this study following conclusions can be obtained.

- The tensile strength of TIG welded joints with filler ER4043 and ER5356 was observed 158.6 MPa and 176.2 MPa respectively.

- The residual stress of TIG welded joints with filler ER4043 and ER5356 was observed $72 \mathrm{MPa}$ and $63 \mathrm{MPa}$ respectively

- To increases the tool rotational speed and decrease the feed rate, leads to increases in heat input in TIG+FSP welded joint.

- The maximum tensile strength (281.1 MPa), microhardness $(107 \mathrm{HV})$ and minimum residual stress $(18.3 \mathrm{MPa})$ for TIG+FSP welded joints with filler ER5356 was observed at tool rotational speed of $1300 \mathrm{rpm}$, traverse speed of 30 $\mathrm{mm} / \mathrm{min}$ with tilt angle 2 .

- The empirical relationships were developed to analyze the tensile strength, \% elongation, residual stress and microhardness of TIG+FSP welded joint of AA6061 and AA7075 at 95\% confidence level for both the filler ER4043 and ER5356.

- Optimized value of tensile stress, percentage elongation, microhardness at nugget zone and residual stress at nugget zone are $253.89 \mathrm{MPa}, 31.05,107.916 \mathrm{HV}$ and $22.83 \mathrm{MPa}$ respectively, whereas the optimized processing parameters i.e. tool rotatonal speed, feed rate and tilt angle are 1300 $\mathrm{rpm}, 45 \mathrm{~mm} / \mathrm{min}$ and $0.955^{\circ}$ respectively for filler ER 4043 .

- Optimized value of tensile stress, percentage elongation, microhardness at nugget zone and residual stress at nugget zone are 266.66 MPa, 29.74, 103.19 HV and 21.66 MPa respectively, whereas the optimized processing parameters i.e. tool rotatonal speed, feed rate and tilt angle are 1278.12 $\mathrm{rpm}, 35.98 \mathrm{~mm} / \mathrm{min}$ and $1.749^{\circ}$ respectively for filler ER5356.
- The grains in the nugget zone in TIG+FSP welded joint was observed much finer than the TIG welded joint at fusion zone.

- The peak temperatures on AS were higher than the RS of $20 \mathrm{~K}$. The heat transfer is analyzed by the effect of different processing parameters of the FSP tool. The temperature at the advancing side is higher than the retreating side.

- The predicted peak values of temperature at the weld region were calculated by the ANSYS software and found the maximum temperature about $515^{\circ} \mathrm{C}$ at tool rotation of 1300 rpm.

- The large dimples and quasi cleavage with a sharp edge and various depths were found on the fractured tensile specimen surface of low tool rotational speed whereas fine dimples were found at high tool rotational speed of TG+FSP welded joints.

\section{References}

[1] Abnar B, Kazeminezhad M, Kokabi A H. Effects of heat input in friction stir welding on microstructure and mechanical properties of AA3003-H18 plates [J]. Transactions of Nonferrous Metals Society of China, 2015, 25(7): $2147-2155$.

[2] Dawood H I, Mohammed K S, Rahmat A, Uday M B. Effect of small tool pin profiles on microstructures and mechanical properties of 6061 aluminum alloy by friction stir welding [J]. Transactions of Nonferrous Metals Society of China, 2015, 25(9): 2856-2865.

[3] Hejazi I, Mirsalehi S E. Mechanical and metallurgical characterization of AA6061 friction stir welded joints using microhardness map [J]. Transactions of Nonferrous Metals Society of China, 2016, 26(9): 2313-2319.

[4] Sato Y S, Urata M, Kokawa H. Parameters controlling microstructure and hardness during friction-stir welding of precipitation-hardenable aluminum alloy 6063 [J]. Metallurgical and Materials Transactions A, 2002, 33(3): 625-635.

[5] Kiral B G, Tabanoglu M, Serindag H T. Finite element modeling of friction stir welding in aluminum alloys joint [J]. Mathematical and Computational Applications, 2013, 18(2): 122-131.

[6] Gemme F, Verreman Y, Dubourg L, Jahazi M. Numerical analysis of the dwell phase in friction stir welding and comparison with experimental data [J]. Materials Science and Engineering A, 2010, 527(16): 4152-4160.

[7] Schmidt H, Hattel J, Wert J. An analytical model for the heat generation in friction stir welding. Modell Simul Mater Sci Eng 2003;12(1):143.

[8] Chao YJ, Qi X. Thermal and thermo-mechanical modeling of friction stir welding of aluminum alloy 6061-T6. J Mater Process Manuf Sci 1998;7:215-33. 
[9] Peel M, Steuwer A, Preuss M, P J (2003) Withers, microstructure, mechanical properties and residual stresses as a function of welding speed in aluminum AA5083 friction stir welds. vol 51, Issue 16, pp 4791-4801

[10] J.Q. Su, T.W Nelson, R.S Mishra, M.Mahoney, "Microstructure investigation of friction stir welding 7050-T651 aluminum, acta materialia, 2002

[11] S.Jana, R.S.Mishra, J.B Baumann, G. Grant, "Effect of stress ratio the fatigue behaviour of a friction stir processed cast Al-Si-Mg alloy, Scripta Materialia 61 (2009), 992-995.

[12] Z.Y.Ma, R.S Mishra, M.W. Mahoney," Super plastic deformation behavior of friction stir processed 7075Al alloy", Acta Materialia 50 (2002), 4419. 4430.

[13] R.S Mishra, Z.Y.Ma, I. Charit, "Friction stir processing: A Novel technique for fabrication of surface composite", Matrial Science and Engineering A 341 (2003) 307-310.

[14] S. Jana, R.S. Mishra, J.A Baumann, G. Grant, “ Effect of process parameters on abnormal grain growth during FSP of a cast Al-Alloy", Material Science and Engineering A, 528 (2010) 189-199.

[15] S.Jana, R.S Mishra, J.B Baumann, “ Effect of friction stir processing on fatigue behavior of an investigation cast Al-7Si-0.6Mg alloy, Acta Materialia, 58 (2010) 989-1003.

[16] Z.Y Ma, R.S.Mishra, M.W Mahoney, R. Grimes, "Effect of Friction Stir Processing on the the kinectic of superplastic deformation in an $\mathrm{Al}-\mathrm{Mg}-\mathrm{Zr}$ Alloy", Metallurgical and Material Transaction, 36A (2005), 1447-1458.

[17] S.R Sharma, R.S Mishra, Z.Y Ma, "Effect of friction stir processing on fatigue behaviour of A356 Alloy”, Scripta Materialia 51 (2004) 237-241.

[18] Z.Y Ma, S.R Sharma, R.S Mishra, “ Effect of Multipass Friction Stir Processing on Microstructure and tensile propeties of a Cast Al-Si Alloy”, Scripta Materialia, 54 (2006) 1623-1626.

[19] Z.Y. Ma, R.S Mishra, M.W Mahoney, “ Superplasticity in Cast A356 induced via friction Stir Processing”, Scripta Materialia 50 (2004) 931 935 .

[20] Jianqing Su, Jiye Wang, R.S Mishra, Ray Xu, " Microstructure and Mechanical Properties of Friction Stir Processing Ti-6Al-4V Alloy”, Material Science and Engineering A 573 (2013) 67-74

[21] Omar S. Salih, Hangan Ou, W.Sun, D.G McCartney, "A review of friction stir welding of aluminum matrix composite", Material and Design 86 (2015) 61-71.
[22] N. Kamp, A. Sullivan, R. Tomasi, J.D. Robson, Modelling of heterogeneous precipitate distribution evolution during friction stir welding process, Acta Materialia 54 (2006) 2003-2014.

[23] M. Maalekian, E. Kozeschnik, H.P. Brantner, H. Cerjak, Comparative analysis of heat generation in friction welding of steel bars, Acta Materialia 56 (2008) 2843-2855.

[24] L. Fratini, G. Buffa, R. Shivpuri, Mechanical and metallurgical effects of in process cooling during friction stir welding of AA7075-T6 butt joints, Acta Materialia 58 (2010) 2056-2067.

[25] S. Mironov, Y.S. Sato, H. Kokawa, H. Inoue, S. Tsuge, Structural response of superaustenitic stainless steel to friction stir welding, Acta Materialia 59 (2011) 5472-5481.

[26] Husain Mehdi , R.S. Mishra (2020), Effect of Friction Stir Processing on Microstructure and Mechanical Properties of TIG Welded Joint of AA6061 and AA7075, Metallography, Microstructure, and Analysis volume 9 pages403-418(2020).

[27] Husain Mehdi , R.S. Mishra (2020), Effect of friction stir processing on mechanical properties and heat transfer of TIG-welded joint of AA6061 and AA7075, Defence Technology (Elsevier) (I.F- 1.26) (accepted), ISSN: 2214-9147, DOI: https://doi.org/10.1016/j.dt.2020.04.014.

[28] Y.S. Sato, Y. Kurihara, S.H.C. Park, H. Kokawa, N. Tsuji, Friction stir welding of ultrafine grained $\mathrm{Al}$ alloy 1100 produced by accumulative rollbonding, Scripta Materialia 50 (2004) 57-60.

[29] G. Buffa, A. Ducato, L. Fratini, Numerical procedure for residual stresses prediction in friction stir welding, Finite Elements in Analysis and Design 47 (2011) 470-476.

[30] C. Hamilton, S. Dymek, A. Sommers, A thermal model of friction stir welding in aluminum alloys, International Journal of Machine Tools \& Manufacture 48 (2008) 1120-1130.

[31] Husain Mehdi, R.S. Mishra (2020), Investigation of mechanical properties and heat transfer of welded joint of AA6061 and AA7075 using TIG+FSP welding approach, Journal of Advanced Joining Processes (Elsevier), ISSN: 2666-3309, vol-1, issue-1, 100003

[32] Husain Mehdi , R.S. Mishra (2020), Influence of friction stir processing on weld temperature distribution and mechanical properties of TIG welded joint of AA6061 and AA7075 Transactions of the Indian Institute of Metals (Springer), (I.F- 1.17) (accepted), ISSN:0975-1645,DOI https://doi.org/10.1007/s12666-020-01994-w.

Cite this article as: Husain Mehdi, R.S. Mishra, New methods to enhance the mechanical characteristics of welded joints of dissimilar Al-alloys by friction stir welding, International Journal of Research in Engineering and Innovation Vol-4, Issue-3 (2020), 168-173. https://doi.org/10.36037/IJREI.2020.4308. 